\title{
Mobile Assisted Language Learning
}

\author{
$1^{\text {st }}$ Ranta Butarbutar* \\ Department of English Education \\ Universitas Musamus \\ Merauke, Indonesia \\ ranta@unmus.ac.id \\ $4^{\text {th }}$ Seli Marlina Raja Leba \\ Department of English Education \\ Universitas Musamus \\ Merauke, Indonesia \\ selly@unmus.ac.id
}

\author{
$2^{\text {nd }}$ Rezky Uspayanti \\ Department of English Education \\ Universitas Musamus \\ Merauke, Indonesia \\ rezky05@unmus.ac.id
}

\author{
$3^{\text {rd }}$ Marni Bawawa \\ Department of English Education. \\ Universitas Musamus \\ Merauke, Indonesia \\ marnibawawa@unmus.ac.id
}

\begin{abstract}
One of the requirements to get competitive human resources internationally is mastery technology in learning. On the other hand, means that human has the ability to use information and communication technology to communicate with cognitive and technical skills. In line with the its definition, MALL is the massive solution. Mobile assisted language learning or language learning utilization based mobile phones. The merits of this study be worthy of helping learners easier understand while language learning process is occurring either guided face to face in the classroom or self-learning out of classroom. Study used classroom action research in gaining data. Seeing initial students' ability, this study designed into three cycles in gathered data. However, 30 students at forth semester of English Department were participants of this study. Study noted the using MALL potential to ameliorate students' ability in the end of cycle. In the final analysis results declares using MALL is pretty effective to encourage student's motivation, built-up selflearning language, aids to enrich vocabulary, promote speaking, grammar and listening skill were greater. Implicitly, MALL has merit as a reference for design massive curriculum and materials development.
\end{abstract}

\section{Keywords: digital literacy, MALL, language learning}

\section{INTRODUCTION}

The development of information and communication technology and industrial revolution has had an influence on the field of education, especially in the learning process. Currently, one of the competencies that must be possessed by disciple to accelerate competitive human resources in the disruption 4.0 era is information technology and communication[1]. Technology promises to change the way students learn and educators teach, bring the era of $21 \mathrm{st}-$ century learning systems and create a student-centered learning environment. Important to realize technology also has the potential to accelerate the process of educational transformation. Through holistic use of technology tools and services not only in the classroom or within the scope of school infrastructure - educational institutions can ensure lean and focused planning and efficient reforms to bring about effective change to improve the quality of student achievement. In line with competitive human resources is needed transformation in education. As [2] define transformation as changing gradually and sustainability to get a better atmosphere than previously. Thus, an alternative to reach higher education quality is to improve the interaction between teacher and students interactively. It is an obligation and force could not be denied.

Similarly, [3 - 6] summarize by an interactive approach and considering that the school is a place for children to adolescents requires brain process of development. Of course, the teacher is the main actor and has responsibility for creating interaction in class requires good ability in various aspects. What a simple measurement apparatus used to see the success of this interaction process? Is every student involved in-class activities? Do students pay attention to the teacher in class without the teacher forcing them to pay attention? How many teachers shout repeatedly in class throughout this interaction period have the students paid their attention?. It is called a classic method that the teacher asked the student to pay attention to without involving them.

By following [7] illustrate an English teacher have disciples to keep silent and listen to the teacher otherwise teacher have disciples do activities by involving them in class debating or play a role to improve their speaking skill. Not to mention Not to mention as [8] confirm anyone can independently or without guided structure to enumerate Buss Application. This application Busuu is the world's largest social network for learning languages, which provides 12 language courses on the web and mobile devices to more than 100 million students worldwide. Participants can register for free or subscribe to a Premium membership to unlock more features such as grammar lessons, offline mode, McGraw-Hill Education language certificate, or our adaptive Vocabulary Trainer. By the same token [9] clarify Busuu is a language learning application like Duolingo that helps you learn dozens of languages from an Android device, including lessons, tests, and everything you need to master a language. Available languages are English, French, Spanish, German, Italian, Portuguese, Polish, Russian, Turkish, Japanese, and Chinese. From this application, you can register for one of the courses available in the language concerned, and start studying. With Busuu, you can practice writing, reading, and listening to languages. Most tests are written, but there are also hearing tests that must be passed to complete the activity correctly. Some of the activities that you will find at Busuu include vocabulary and grammar exercises, audio dialogue, and, of course, interactive tests. If you pass an interactive 
test, you will advance to new levels in your language. Additionally, Busuu is an excellent language learning application, with a clean interface, easy to use and has a variety of content. It requires Android 2.3 or higher level.

Equally important, its application has three merits, e.g. student-centered learning, system approach, and empower of learning references. In light of curriculum 2013, one famous strategy is student centered learning (SCL). Pertaining it, teacher has role as facilitator, provided appropriate and vary learning media for teaching language for students e.g. Bussu application. Additionally, learning process by implement Student Centered Learning must provide space for students to learn according to their interests, personal abilities, learning styles. Students naturally differ from one another both in their interest in a teaching material, their intellectual abilities and in their preferred learning style. Correspondingly, this study aims to present and covers of research question: how the effect of using mobile-based application learning language?

\section{RESEARCH METHODS}

In applying Buss as a medium in improving students' reading, speaking and vocabulary abilities, this study was

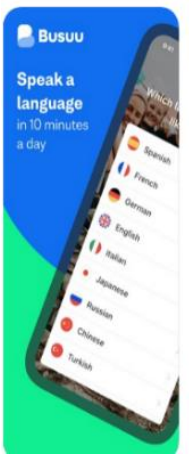

Fig. 1.

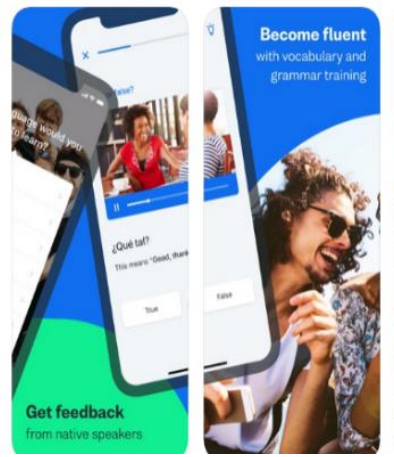

Busuu Platform levels

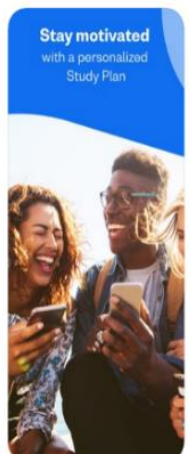

designed with classroom action research. The design of this study is intended to see the changes experienced by students as the subject of this study from the start of cycle I, cycle II, and at the end of cycle III. In the process of collecting data, it is, of course, needed a tool as an instrument consisting of observation and tests as long as the subject gets action implementing the Buss application during the learning process takes place.

In accordance with the figure 1 above shows students' achievement can be divided into three levels to enumerate learn, stay motivated, and become fluent level. It means student who get learn describes he still in learning position. Thus, student in stay learned means to be continue for the next level until get become fluent or advance in one skill. After they got become fluent level, they could be change into another skill, vice versa. Investigating how far the effect of using mobile assisted in language learning.

\section{RESULTS AND DISCUSSION}

Referring to the actions done in the classroom, study noted that students' achievement as results and can be seen through three cycles. But before implementing mobile as media in language learning, researcher and teacher collaborated to observe participants' characteristics initially.

\section{A. First Cycle}

Starting first cycle, teacher had students to install Busuu application in their mobile, learnt its feature, chosen level as their ability.

As a beginner level, the subjects of this study used the Buss application to practice pronunciation correctly. Data observations show that $80 \%$ or 24 students of them get level 1. It indicated that their pronunciation incomprehensibly. For example, in pronouncing the word "development" they pronounced [depelop'men], and it is should be pronounced [di'veləpmənt]. It means that their pronunciation level is still very low, the problem of pronunciation is serious so it can't be understood. Students still need time with high frequency on a regular basis to get better results. In such cases it is also planned to increase the duration of practice for each student in the second cycle. Researcher reflected at this stage. then planning a more creative strategy so that their pronunciation is better. The teacher asks students to listen to new words, then repeat them ten times so that student's pronunciation is more increasing automatically due to they heard directly from native speaker.

\section{B. Second Cycle}

In line with preplanning in the previous cycle, at this stage student are still practicing with the same application, the Buss application. But what is different in this session is the ability to listen is also assessed. Students are asked to choose Buss again with intermediate level and goals for school needs. Furthermore, the menu implemented is conversation to the native speaker in order to each student can listen to the correct conversation directly from native speakers. It was a merit of this application, besides student could choose any topics for their drill simultaneous listening skill is improved.

\section{Third Cycle}

What's interesting about this learning application is that the more often the student will be more proficient. Especially in vocabulary, when compared to the amount of vocabulary they got from the first cycle to the end of the third increased continues scores at 50, 70, and 90. Furthermore, this increasing in vocabulary will affect the level of fluency in speaking by itself. We build each lesson so that it gives you everything you need to begin communicating on a particular topic. For example, in the following lesson, 'Our body', in the English A1 course, student can be started with a Vocabulary unit on parts of body, then another one on how to understand directions. By the same token, researcher showed much more basic grammar, with a unit on how to say 'there is' or 'there are' and then another grammar unit on prepositions of place (words like 'for', 'under or 'above'). Furthermore, after students already understood these units, they are ready to start communicating with the language they have studied. Then teacher or researcher give them a short writing assignment, asking student to mention their parts of body. In like manner, the student's report will be sent to members of our community who will give students kindly and useful feedback on your writing. On the dashboard there is also a voice recording exercise, where students could be trained and drilled describing their parts of body by matching their voice into a dialogue and listening back to hear how students sound. 
All their lessons help build students' conversational skills gradually; starting with the vocabulary and grammar they need and then giving you simple but challenging exercises where you get to use the language you've learned in a real communicative task. It's these practice tasks that really build their fluency; entailing them to create and more creative with the language they have studied - almost as well as a face to face conversation with a native speaker, but not nearly as scary. For more detail, student's scores can be shown by following figure 2 below:

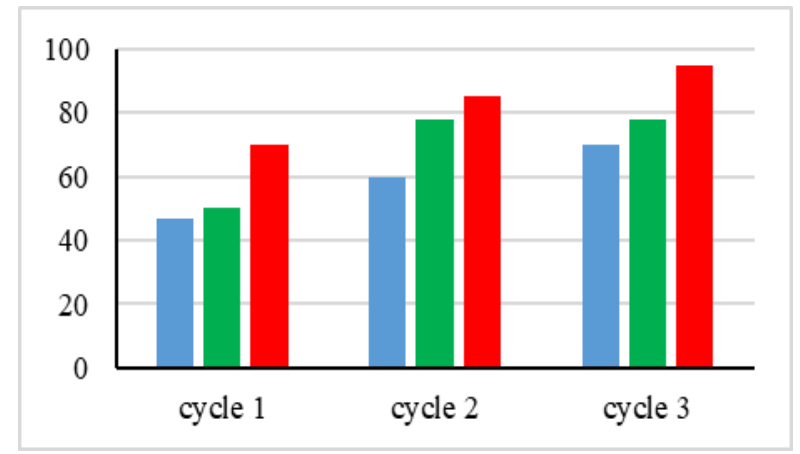

Fig. 1. Students' achievement

In the end cycles, students' results could be seen by chart 1 above. The results show that mobile-based learning is implemented in 3 cycles. Furthermore, the results obtained by students are categorized into three abilities, namely speaking, listening, and vocabulary. In cycle 1 the value of speaking 47 , listening 50 , and vocabulary 70 . Then there was an increase in cycle 2 in the value of speaking 60, listening 78 , and vocabulary 85 . And in the last cycle, there was a pretty significant increasing their scores of speaking 70 , listening 78 , and vocabulary to 95 . Comparatively, as [10] states showing games board can be improving spoken English.

English frequently. [11] asserts the using WhatsApp application is effective to ameliorate students' reading ability. Contrary with [12] conclude in the midst of the rise of super modern technological advances today it is precisely the local culture-based learning that needs to be passed on to the younger generation. it aims to introduce and pass down the diversity of local culture to the younger generation as the nation's successors. On the other hand, by implementing this application, Busuu, students can be mastered simultaneously integrated four skills.

\section{CONCLUSION}

Transforming education in improving excellent human resources for great Indonesia needs some strategies. One of the strategy is the using technology to support an innovative learning process. The using technology accelerate learning process, it can be independent occur in long distance and unlimited time. In light of application Busuu, learners could be improved their vocabulary, speaking, and listening using it without face to face in the classroom, study noted students freely chosen skills refers to their needs. interestingly they could be learnt more than one foreign languages besides English. And those are merits of this application.

In like manner, in improving qualified human resources beside using technology, learners also given chance largely on the job training, internship or house training. Listening. The rapid development of information Technology in the current era of globalization cannot be avoided any more influence on the world of education. The global demands the world of education to always and constantly adjust technological developments to efforts in improving the quality of education, especially adjusting the use of information and communication technology for education, especially in the learning process.

\section{ACKNOWLEDGMENT}

My great thanks goes to Rector Universitas Musamus, Merauke who fund publication of this project.

\section{REFERENCES}

S. E. Rivers and M. A. Brackett, "Transforming education through scientifically rigorous intervention approaches: A call for innovations in the science of emotional intelligence," Trab. Present. a la Natl. Sci. Found. como parte SBE, 2020.

B. Zou, X. Yan, and H. Li, "Students' Perspectives on Using Online Sources and Apps for EFL Learning in the MobileAssisted Language Learning Context," in Language Learning and Literacy: Breakthroughs in Research and Practice, IGI Global, 2020, pp. 515-531.

[3] D. Kellner and J. Share, The critical media literacy guide: engaging media and transforming education. Brill, 2019

[4] O. B. Olusola, "Instructional Technology an Effective Panacea for Dynamic Education Transformation in Learning: Disseminating Tools for Learning," in The Roles of Technology and Globalization in Educational Transformation, IGI Global, 2020, pp. 127-137.

[5] K. Buckreus and M. Ally, "Smart' Practices: Machine Intelligence for Transforming Pedagogy and Learning," in Emerging Technologies and Pedagogies in the Curriculum, Springer, 2020, pp. 53-73.

[6] I. Montiel, J. Delgado-Ceballos, N. Ortiz-de-Mandojana, and R. Antolin-Lopez, "New Ways of Teaching: Using Technology and Mobile Apps to Educate on Societal Grand Challenges," J. Bus. Ethics, vol. 161, no. 2, pp. 243-251, 2020.

[7] P. M. Sullivan, J. L. Lantz, and B. A. Sullivan, Handbook of Research on Integrating Digital Technology with Literacy Pedagogies. IGI Global, 2019.

[8] M. B. Ulla, W. F. Perales, and V. N. Tarrayo, "Integrating Internet-based applications in English language teaching: Teacher practices in a Thai university," Issues Educ. Res., vol. 30, no. 1, pp. 365-378, 2020.

[9] F. Nami, "Educational smartphone apps for language learning in higher education: Students' choices and perceptions," Australas. J. Educ. Technol., pp. 82-95, 2020.

[10] J. York, "Promoting Spoken Interaction and Student Engagement With Board Games in a Language Teaching Context," in Global Perspectives on Gameful and Playful Teaching and Learning, IGI Global, 2020, pp. 1-26.

[11] R. Butarbutar, "The Study Impact Of Whatsapp Group On Critical Reading Skill," MAGISTRA J. Kegur. dan Ilmu Pendidik., vol. 6, no. 1, pp. 45-51, 2019.

[12] R. Butarbutar, R. Uspayanti, N. Manuhutu, and S. T. Palangngan, "Analyzing of puzzle local culture-based in teaching english for young learners," in IOP Conference Series: Earth and Environmental Science, 2019, vol. 343, no. 1, p. 12208. 